\title{
Rapid high throughput template preparation (rHTTP) method: a novel cost effective method of direct PCR for a wide range of plants
}

Prassan Choudhary, Sudipta Das, Hillol Chakdar, Arjun Singh, Sanjay Kumar Goswami and Anil Kumar Saxena

\begin{abstract}
Background: Conventional plant DNA isolation methods are complex, time consuming and require technical expertise. These limitations were overcome using the DNA isolation kits which, however significantly add to the research costs. Hence the present study was aimed to develop a high throughput, rapid and inexpensive method of PCR ready DNA template preparation from plant materials.

Methods: Concentration of SDS in lysis buffer, amount of starting material, period and temperature for lysis were optimized for obtaining PCR ready templates from plant materials. The method was tested using RAPD and ITS specific primers for different plant species like rice, wheat, mustard, pea, soybean, pigeonpea, tomato, maize, march lilly, bougainvillea, Indian blanket flower, nerium, petunia, purple pirouette petunia, moses-in-the-cradle, golden cane palm, duranta, periwinkle, chrysanthemum and two xerophytes viz. Dipterygium glaucum and Crotaleria burhia. SSR markers RM18398 and RM26108 showed successful amplification in rice varieties Improved Pusa Basmati 1 and KS Dev 12. The effectiveness of the method was tested using fresh as well as 1 year old tissues. The storability of the lysate was also tested.

Results: In this report, we developed a novel method called rapid high throughput template preparation (rHTTP) method to prepare PCR ready DNA templates. Most striking feature of this technique is that it can be done anywhere where water can be boiled by any means. Using rHTTP method, PCR ready templates can be prepared in just 10 min. Robust and reproducible amplification for all the test plants were recorded with RAPD, plant ITS primers and SSR markers following this method. rHTTP methods works well for both fresh as well as old plant tissues. The lysates had a shelf life of 1 month when stored at $4{ }^{\circ} \mathrm{C}$ and 3 days when stored at room temperature.

Conclusions: rHTTP method has several advantages over the other protocols like ease of execution, no requirement of tissue grinding/liquid nitrogen/hazardous chemicals and above all, equally effective for both fresh and old samples. Using this method, costs per prep comes down 10-50 times as compared to most commercial kits. This method can be used for on-field experiments like molecular diagnostics, varietal identification etc.
\end{abstract}

Keywords: Plant- DNA- high throughput- PCR-SSR

\footnotetext{
* Correspondence: hillol.chakdar@gmail.com

ICAR-National Bureau of Agriculturally Important Microorganisms (NBAIM),

Mau, Uttar Pradesh 275103, India
}

(c) The Author(s). 2019 Open Access This article is distributed under the terms of the Creative Commons Attribution 4.0 International License (http://creativecommons.org/licenses/by/4.0/), which permits unrestricted use, distribution, and reproduction in any medium, provided you give appropriate credit to the original author(s) and the source, provide a link to the Creative Commons license, and indicate if changes were made. The Creative Commons Public Domain Dedication waiver (http://creativecommons.org/publicdomain/zero/1.0/) applies to the data made available in this article, unless otherwise stated. 


\section{Background}

DNA extraction is one of the most important and critical steps of a molecular biology laboratory. The conventional methods of DNA isolation involved multiple steps to rupture the cells and purify nucleic acids from the complex mixture of macromolecules using hazardous chemicals like phenol, chloroform etc. Such methods were also considerably lengthy and impeding the speed of work when DNA had to be isolated from a large number of samples. In the early 1990s, efforts were being made to simplify the cumbersome methods of obtaining good quality plant DNA which could be useful for downstream processing [1-4]. Rapid DNA fingerprinting techniques were also developed necessitating the scientists to work towards reducing the time and effort required for DNA isolation [4]. Varma et al. (2007) reviewed the various aspects of plant DNA extraction complexities and concluded that the chemical heterogeneity and diversity of plant systems rendered it very difficult for a single method to be employed for isolating pure, restrictable plant genomic DNA [5-11]. In 1993, Wang et al. reported a rapid $\mathrm{NaOH}$ based method for DNA template preparation for direct PCR [12]. The methodology was reported to be unsuitable for amplification of products more than $600 \mathrm{bp}$ and consequently, Steiner et al. developed a new buffer (ROSE buffer) composition for DNA extraction [13]. Gradually, a number of modifications of the $\mathrm{NaOH}$ based methods have been reported by a number of researchers [14-17]. Apart from $\mathrm{NaOH}$, sucrose has also been used for rapid extraction of DNA from plant tissues [18]. Few "touch and go" methods of direct PCR have also been reported [18, 19]. Research in this regard got a flip with the development of commercial kits which mostly rely on spin columns that capture the nucleic acids from cleared homogenates. However, the use of commercial kits attracts a considerable financial burden for research works. Despite the continuous development of a number of rapid DNA isolation methodologies since last 25 years, their use has been very limited. Satya et al. (2013) emphasized that reliability, wide application, storability of the extracts or even sometimes simple mental bias might have been the reasons behind their poor popularity among the scientific community.

On comparison of few reported DNA template preparation methods, it was realized that most of the so called "rapid methods" still require liquid nitrogen or lyophilized tissue, essentially grinding of the tissue and use of instruments like centrifuge or vortex. These operations reduce the sample processing efficiency as many of these had to be done individually or separately for each sample. Hence, these so called "rapid methods" seemed not to be very rapid when we need to process hundreds of samples together. However, such methodologies have potential to be used for large scale genotyping, DNA barcoding, molecular breeding and even in molecular diagnostics. In a recent report, Wang et al. (2016) conclusively demonstrated the use of rapid DNA template preparation in loop-mediated isothermal amplification (LAMP) for field detection of transgenic lines of rice in China.

Therefore, there was a need to develop a really rapid, simple method which can be used to yield PCR ready templates from a wide range of plant species and simultaneously cheaper than the commercially available kits. In this study, we report a novel, rapid and inexpensive method to prepare PCR ready template from a variety of plants and showed its usefulness in molecular biology experiments.

\section{Results}

\section{Development and optimization of the method}

The results on optimization of SDS concentration in lysis buffer revealed that highest DNA yield was achieved when $1 \%$ SDS was used (Table 1). The concentration of SDS did not specifically influence the purity of DNA. For further optimization studies, 1\% SDS was used for lysis. Among the two different amounts of tissue used for lysis, the results on DNA yield was significantly better when two leaf discs $(\sim 3.2 \mathrm{mg})$ were used as a start material for lysis (Table 1). Among the two time periods (10 or $20 \mathrm{~min}$ ) used for lysis,10 min was finally selected as the DNA yield was higher as compared to $20 \mathrm{~min}$ of lysis (Table 1). Hence, the optimized protocol for DNA template preparation included lysis of two discs $(\sim 3.2$ $\mathrm{mg}$ ) of leaf tissue in $100 \mu \mathrm{l}$ of $1 \%$ SDS and heated for 10 min at $99^{\circ} \mathrm{C}$ in a thermal cycler.

The success of the DNA template was judged by PCR amplification using RAPD primers (OPB06 and OPB07). An aliquot of $2.5 \mu \mathrm{l}$ of crude lysate, $10 \mathrm{X}$ and $20 \mathrm{X}$ diluted lysate were used as a template for two series of amplification reactions with or without BSA in PCR reactions for two different reaction volumes viz. $20 \mu \mathrm{l}$ and $40 \mu \mathrm{l}$. No amplification was achieved with the crude lysate in presence or absence of BSA (Fig. 1). Likewise the bacterial DNA dissolved in $0.1 \%$ SDS did not yield any amplification product. Both 10X and 20X diluted lysate yield amplified products with no significant differences in the amplification profile both in presence or absence of BSA (Fig. 1). Therefore, 20X diluted lysate was used for further validation of our protocol for DNA template preparation followed by PCR amplification with no addition of BSA in the reaction mixture.

\section{Effectiveness of the optimized method}

The usefulness of this rHTTP method was validated for 11 different rice varieties and DNA template obtained resulted in robust RAPD profile upon PCR amplification 
Table 1 DNA quality and yield in lysates prepared with different concentrations of SDS, different amount of tissue and different time duration

\begin{tabular}{|c|c|c|c|}
\hline Parameters & & DNA Purity $\left(A_{260} / A_{280}\right)$ & DNA Concentration $(\mathrm{ng} / \mathrm{\mu l})^{\mathrm{a}}$ \\
\hline \multirow[t]{10}{*}{ SDS conc. (\%) } & 0.5 & 1.03 & $451.67 \pm 8.82$ \\
\hline & 1.0 & 1.01 & $768.33 \pm 6.01$ \\
\hline & 1.5 & 1.03 & $376.67 \pm 4.41$ \\
\hline & 2.0 & 1.04 & $252.17 \pm 1.48$ \\
\hline & 2.5 & 1.03 & $438.33 \pm 14.24$ \\
\hline & 3.0 & 1.04 & $261.17 \pm 21.17$ \\
\hline & 3.5 & 1.05 & $218.33 \pm 3.33$ \\
\hline & 4.0 & 1.06 & $260.17 \pm 3.06$ \\
\hline & 4.5 & 1.05 & $326.67 \pm 1.67$ \\
\hline & 5.0 & 1.04 & $446.67 \pm 14.81$ \\
\hline \multirow[t]{2}{*}{ Amount of tissue } & One disc ( 1.6 mg) & 1.06 & $420.00 \pm 10.08$ \\
\hline & Two $\operatorname{disc}(\sim 3.2 \mathrm{mg})$ & 1.04 & $760.00 \pm 6.75$ \\
\hline \multirow[t]{2}{*}{ Time durations } & $10 \mathrm{~min}$ & 1.08 & $876.67 \pm 37.12$ \\
\hline & $20 \mathrm{~min}$ & 1.05 & $808.33 \pm 6.01$ \\
\hline
\end{tabular}

${ }^{a}$ DNA concentration is represented as Mean $\pm \mathrm{SE}$

(Additional file 1: Fig. S1). The leaf lysates of wheat, pigeonpea, mustard, soybean, pea, tomato, maize, march lilly, bougainvillea, Indian blanket flower, nerium, petunia, purple pirouette petunia, moses-in-the-cradle, golden cane palm, duranta, periwinkle, chrysanthemum, Dipterygium glaucum and Crotaleria burhia yielded a $\sim 700 \mathrm{bp}$ amplicon with universal plant specific primers for internal transcribed spacer (ITS) region (Fig. 2 a-d). The rHTTP method was equally effective for old tissues as lysis of 2 months old rice leaves of four different varieties yielded a DNA template that gave strong amplification using RAPD primer OPB07 (Additional file 2: Fig. S2). Figure 3 showed

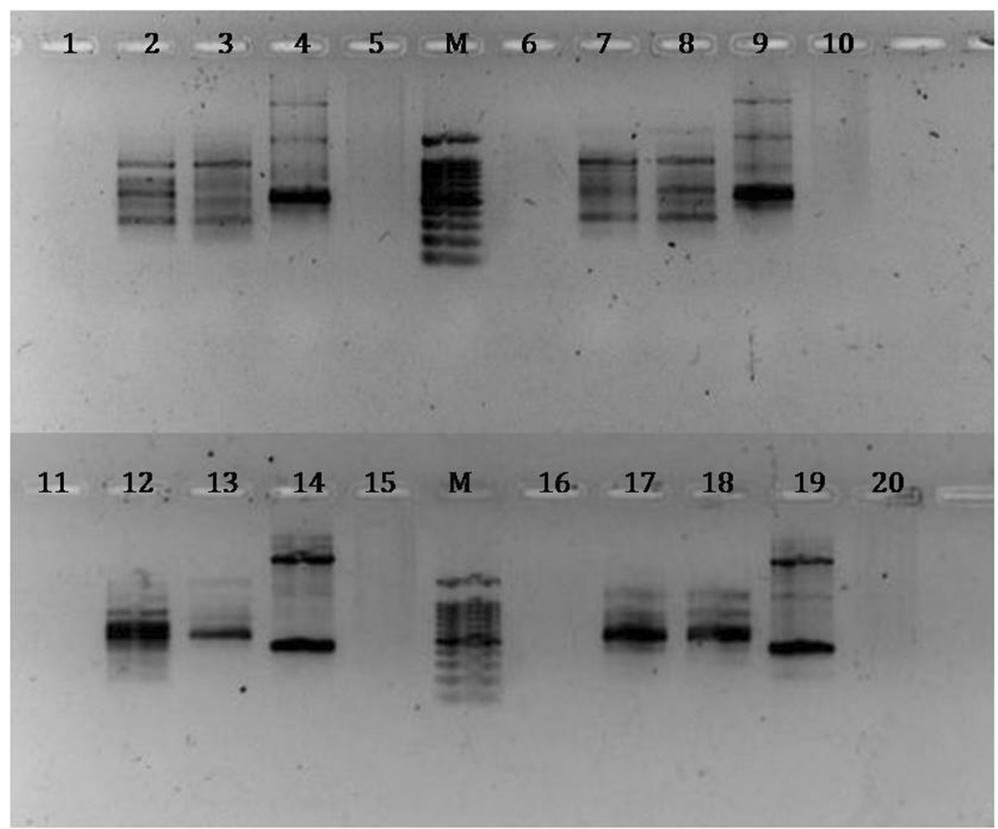

Fig. 1 OPB6 (lane 1 to 10) and OPB7 (lane 11 to 20) primers showed good amplification results using10X and 20X dilutions of the crude template DNA lysate. Lane 1:Crude lysate (Cr) -without 1\% BSA (BSA); Lane 2: 10 times diluted (10X) lysate-BSA ; Lane 3: 20times diluted (20X) lysate-BSA ${ }^{-}$; Lane 4:Bacterial DNA (Bac)-BSA-; Lane 5: Bac- with 0.1\% SDS-BSA ; M: 100 bp marker (Promega); Lane 6: Cr-with 1\% BSA (BSA ); Lane 7: 10X lysate -BSA ${ }^{+}$; Lane 8: 20X lysate-BSA ${ }^{+}$; Lane 9: Bac-BSA ${ }^{+}$; Lane 10: Bac- with 0.1\% SDS-BSA ${ }^{+}$; Lane 11: Cr-BSA ; Lane 12: 10X lysate-BSA ; Lane13:20X lysate-BSA ; Lane 14: Bac-BSA ${ }^{-}$; Lane 15: Bac- with 0.1\% SDS-BSA ${ }^{-}$; M: 100 bp marker (Promega); Lane 16: Cr-BSA ${ }^{+}$; Lane 17: 10X lysate$\mathrm{BSA}^{+}$; Lane 18: 20X lysate-BSA ${ }^{+}$; Lane 19: Bac-BSA ${ }^{+}$; Lane 20: Bac- with 0.1\% SDS- BSA ${ }^{+}$ 


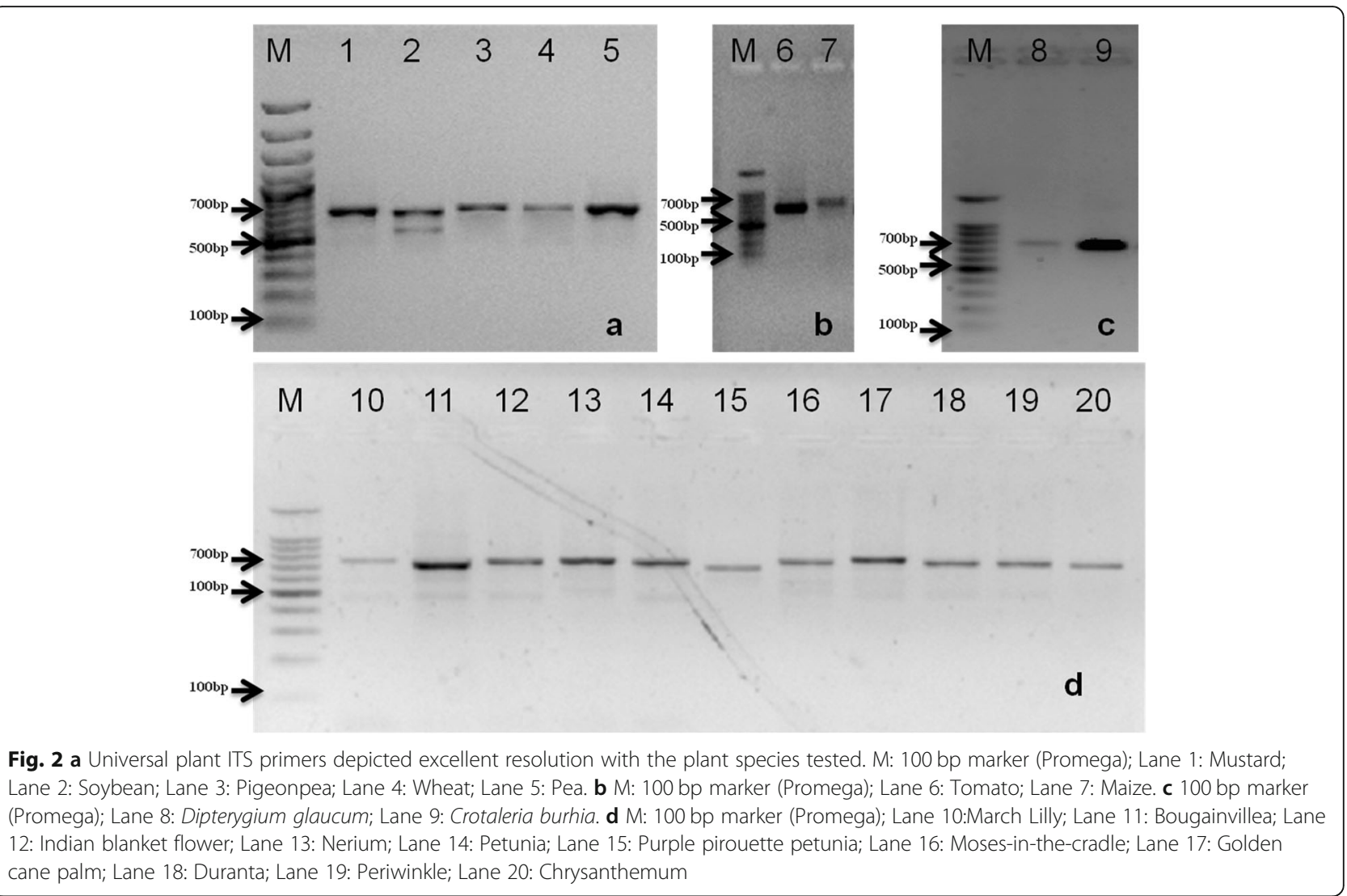

the results of PCR using templates stored at $-20{ }^{\circ} \mathrm{C}$ for 30 days. DNA templates prepared following rHTTP method showed intense bands of ITS regions of the tested crop plants. This indicated that the DNA template preparation using rHTTP method was

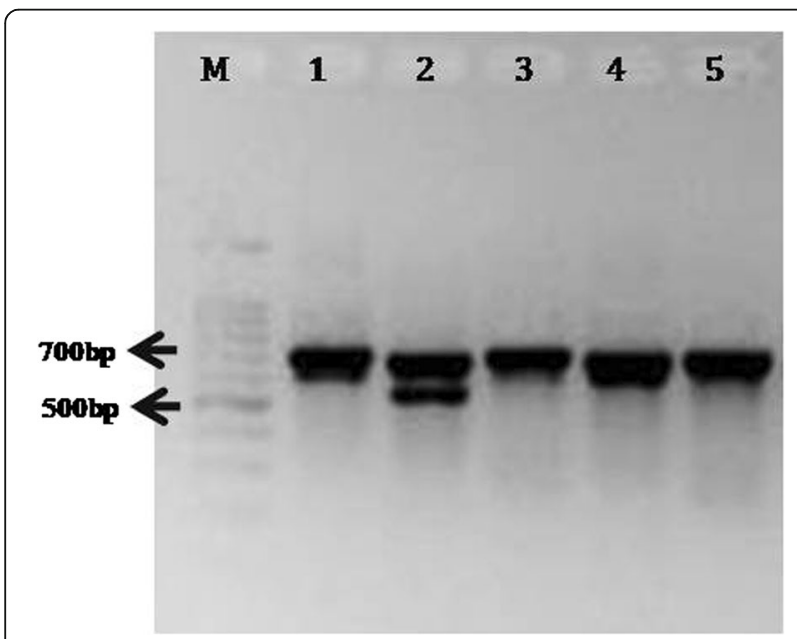

Fig. 3 ITS amplification using 30 days old template DNA of the different plant species stored at $-20^{\circ} \mathrm{C}$. M: $100 \mathrm{bp}$ marker (Promega); Lane 1: Mustard; Lane 2: Soybean; Lane 3: Pigeonpea; Lane 4: Wheat; Lane 5: Pea stable over 1 month. In another experiment, the lysates were kept at room temperature $\left(\sim 20-22^{\circ} \mathrm{C}\right)$ and checked for PCR amplification after 3 days. Additional file 3: Fig. S3 showed that even after storage of 3 days at room temperature, enough DNA remained in the lysate for PCR amplification.

The validated rHTTP protocol yielded a strong ITS amplicon even when boiling water $\left(100-102^{\circ} \mathrm{C}\right)$ was used for 10 and $20 \mathrm{~min}$ instead of heating the lysis mixture in thermal cycler. Strong ITS amplification was observed for both the time periods (Fig. 4).

SSR markers RM18398 (305 bp) and RM26108 (195 bp) showed good amplification with template prepared by rHTTP method as shown in Fig. 5a-b.

Comparative analysis of RAPD profiles of two rice varieties was done and amplification of ITS region following the different protocols detailed in methods revealed positive results with excellent resolution with newly developed rHTTP method and protocol described by Satya et al. (Figs. 6 and 7). Protocols developed by Steiner et al. (1995) and Wang et al. (2016) failed to yield any amplification product or RAPD profiles. In case of the method described by Wang et al. (2016), very faint amplicon resulted in case of rice variety HUR 917 (Fig. 7). 


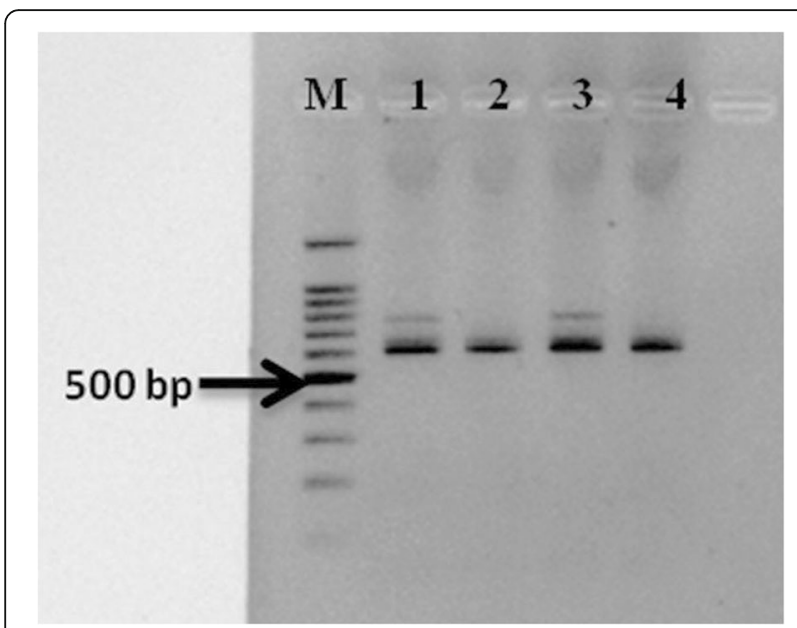

Fig. 4 Amplification of ITS region of rice (varieties Improved Pusa Basmati 1 and KS Dev 12) using templates prepared in boiling water for 10 and 20 min. M: 100 bp marker (Promega); Lane 1: Improved Pusa Basmati 1_10 min; Lane 2: KS Dev 12_10 min; Lane 3: Improved Pusa Basmati 1_20 min; Lane 4: KS Dev 12_20min

\section{Discussion}

In the present study, we have developed a simple, rapid, inexpensive protocol to prepare DNA template for PCR assays. In the rHTTP method development, the two most important factors were the concentration of SDS and the dilution factor. It is a well-known fact that SDS, an anionic detergent is inhibitory for Taq Polymerases [20]. In the present study also it was observed that bacterial DNA containing a final concentration of $0.0125 \%$ SDS in PCR reactions did not produce any amplification but amplification was obtained in bacterial DNA devoid of SDS. SDS has been listed among the chemicals having low concern regarding its environmental risks according to the United States Environmental Protection Agency and other relevant studies [21]. No amplification in case of crude extract from rHTTP lysates could be attributed to high concentration of both SDS $(0.125 \%)$ and DNA $(768.3 \mathrm{ng} / \mu \mathrm{l})$. However, 10X and 20X diluted lysates for which the final concentration of SDS were 0.0062 and $0.0031 \%$ respectively showed strong amplifications. Despite no variation in amplification patterns between $10 \mathrm{X}$ and 20X diluted lysates, the latter was chosen to completely rule out any chance of presence of PCR inhibitors. Earlier also, Satya et al. (2013) emphasized that the dilution factor was the most important factor for success of such direct PCR methods [15].

Although, available literature showed a number of reports $[12-15,18]$ for rapid DNA template preparation for direct PCR assay, their use is still very limited. It has been reported that reliability, reproducibility of such techniques, shelf life of the extracts, quality and quantity of the DNA extracted etc. might have affected the utility and popularity of such techniques [15]. However, most of the techniques still require a good amount of instrumentation and tissue grinding which is probably the most monotonous act of any molecular biology laboratory. In many of these methods, liquid nitrogen or lyophilization is required which further add to the costs involved in these techniques. The rHTTP method developed in this study requires almost no technical expertise to execute and it requires no tissue grinding, vortexing or centrifugation. One most striking feature of this method is that it can be used outside any laboratory and without any sophisticated equipment. The only thing required is a means to boil water. Hence, the rHTTP method can be used for on-field experiments like molecular diagnostics, varietal identification, plant genotyping etc. Wang et al. (2016) reported a $\mathrm{NaOH}$ based modified DNA extraction protocol which they used for identification of transgenic lines in China [14]. However, the method reported by Wang et al. (2016) did not produce good results when we compared it to our method along with few other methods. The rHTTP method in

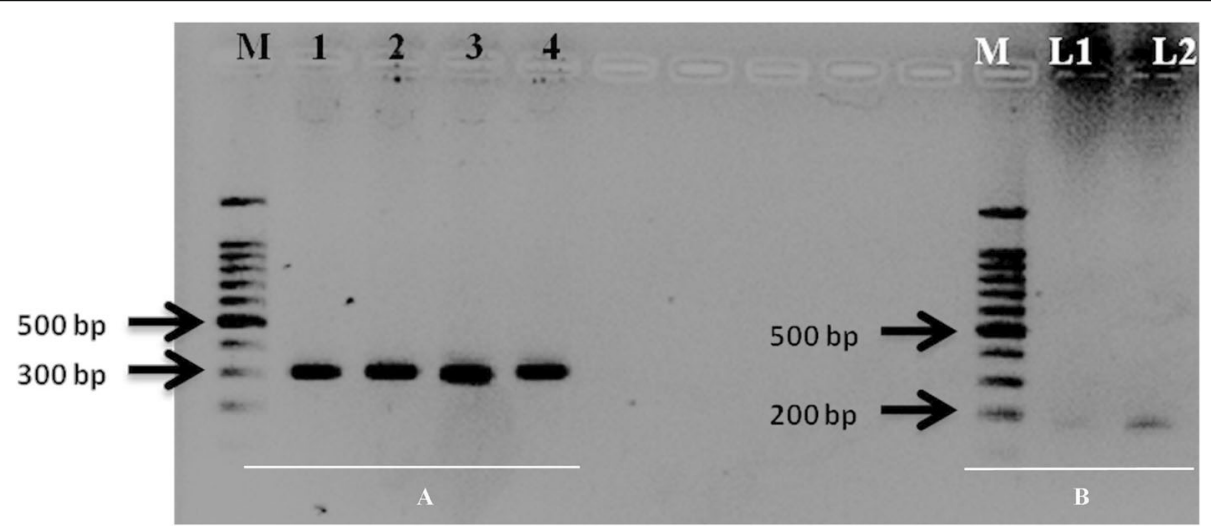

Fig. 5 Amplification of SSR markers RM18398 (Panel A) and RM26108 (Panel B) showed successful amplification in rice varieties. Panel A: M: 100 bp marker (Promega); Lane 1: Pusa basmati 1121; Lane 2: Improved Pusa Basmati 1; Lane 3: KS Dev 12; Lane 4: MTU 5204. Panel B: M: 100 bp marker (Promega); L1: Improved Pusa Basmati 1; L2: KS Dev 12 


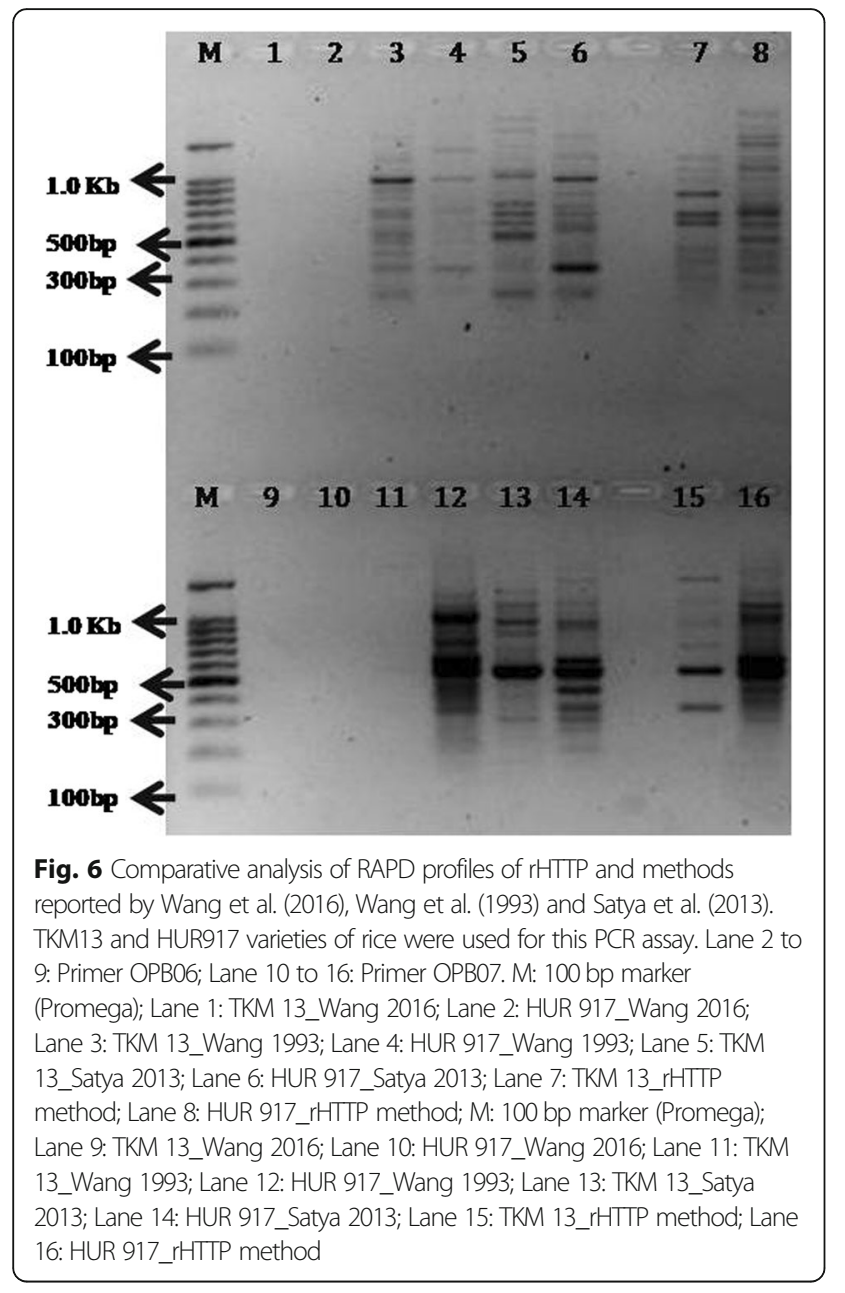

conjunction with isothermal amplification technology can be a revolution in case of molecular diagnostics.

rHTTP method is high throughput method which can bring down the average sample processing time to few seconds. For example, if we want to process 100 samples at a time, the time required will be $10 \mathrm{~min}$ plus the time required for dispensing the lysis buffer and time required for making dilutions. However, for the same 100 samples, the other methods as well as any standard kit will take hours as the samples have to be ground or vortexed or centrifuged individually or in a series of very limited numbers. We have made a comparison with five other methods of rapid DNA template preparation and few commercially available kits for plant DNA extraction (Tables 2 and 3) with special reference to time, cost and instrumentation. Thermo Fisher Scientific Phire Plant Direct PCR Kit recommends the use of young leaves and essentially requires Phire Hot Start II DNA Polymerase which significantly increases the cost per sample and the use of commonly available Taq polymerases is not applicable in this case. Its dilution protocol involves tissue grinding as well as spin centrifuge which increases time and effort. Among the commercial kits available globally, only the QuickExtract ${ }^{\text {mi }}$ DNA Plant DNA Extraction Solution marketed by Lucigen, USA is comparable to rHTTP method in terms of time and requirement of instrumentation. However, the sample needs to be heated at two different temperatures in case of this kit which in turn necessitates the use of a thermal cycler or a heating device with instant temperature controller. On the other hand, rHTTP method can be executed using boiling water which eliminates the temperature controlling step altogether. Nonetheless, the cost for template preparation per sample for this kit is almost 10 times higher as compared to rHTTP method. In majority of the commercially available kits, the cost per preparation ranges between \$ 3-4.5 (INR 200-300) while the same is approximately \$ 0.06 (INR 4.5; Additional file 4: Table S3) per preparation i.e., almost 50-75 times lesser for rHTTP method (Table 3). However, we believe that the rHTTP method is more suitable for PCR based studies where the quality of the DNA can be sacrificed to

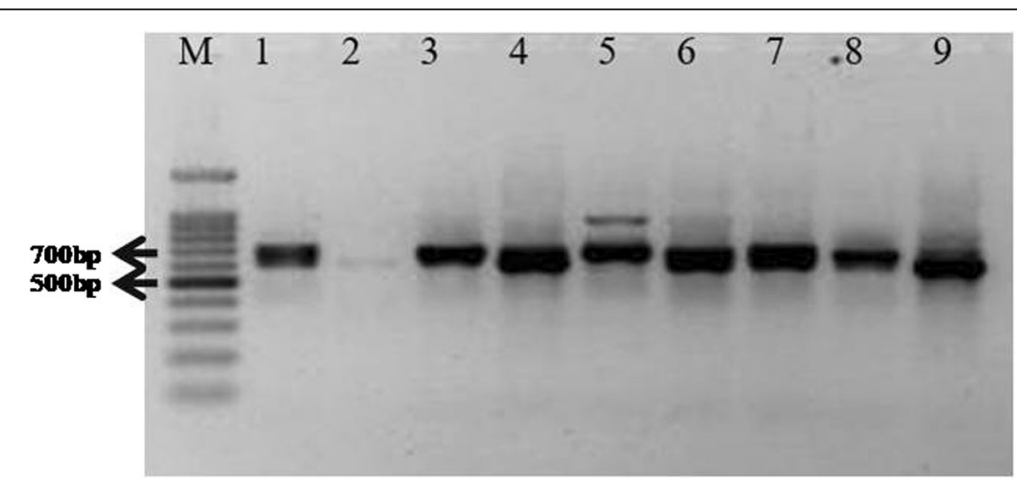

Fig. 7 Comparative amplification of rice ITS using universal primer. Rice varieties Rajendra Sweta, HUR917, and TKM13 were used for the assay. M: 100 bp marker (Promega); Lane 1: TKM 13_Wang 2016; Lane 2: HUR 917_Wang 2016; Lane 3: TKM 13_Wang 1993; Lane 4: HUR 917_Wang 1993; Lane 5: TKM 13_Satya 2013; Lane 6: HUR 917_Satya 2013; Lane 7: TKM 13_rHTTP method; Lane 8: HUR 917_rHTTP method; Lane 9: Rajendra sweta_rHTTP method 


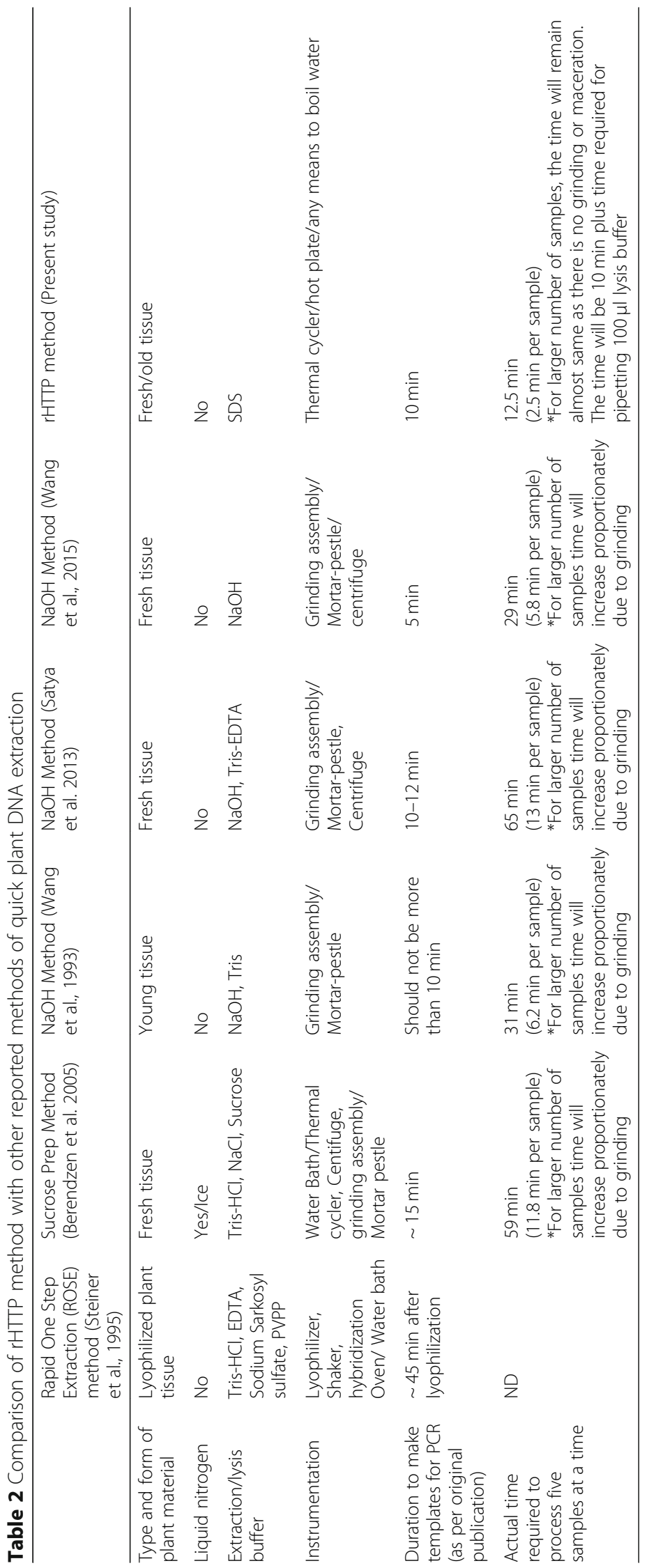


Table 3 Comparison of rHTTP method with few commercially available kits

\begin{tabular}{|c|c|c|c|}
\hline Kits/methods & Time required per sample & Instrumentation & Cost \\
\hline $\begin{array}{l}\text { DNeasy Plant Mini Kit } \\
\text { (Qiagen) }\end{array}$ & $\sim 60 \mathrm{~min}$ & $\begin{array}{l}\text { Grinding assembly/ Mortar-pestle, Centrifuge, vortex } \\
\text { (6 centrifugation steps) }\end{array}$ & INR 282/- per prep \\
\hline $\begin{array}{l}\text { Synergy }^{\mathrm{TM}} 2.0 \\
\text { (OPS Diagnostics) }\end{array}$ & $43 \mathrm{~min}$ & $\begin{array}{l}\text { Centrifuge, vortex } \\
\text { (5 centrifugation steps) }\end{array}$ & INR 153/- per prep \\
\hline $\begin{array}{l}\text { Plant DNA isolation reagent } \\
\text { (Takara) }\end{array}$ & $30 \mathrm{~min}$. & Centrifuge, vortex (3 centrifugation steps) & INR 138/- per prep \\
\hline $\begin{array}{l}\text { Phire Plant Direct PCR Kit } \\
\text { (Thermo Fisher Scientific) }\end{array}$ & - & $\begin{array}{l}\text { Thermal cycler (sample lysis and PCR done in a single tube). } \\
\text { Crushing and spinning required in Dilution protocol }\end{array}$ & INR 51/- per prep \\
\hline $\begin{array}{l}\text { QuickExtract }{ }^{\mathrm{TM}} \text { Plant DNA } \\
\text { extraction solution } \\
\text { (Lucigen) }\end{array}$ & $8 \mathrm{~min}$ & $\begin{array}{l}\text { Heating device with temperature controller } \\
\text { (it requires incubation at two different temperatures) }\end{array}$ & INR 40/- per prep \\
\hline rHTTP method & $10 \mathrm{~min}$ & Thermal cycler/ heating device/ any means to boil water & INR 4.5/- per prep \\
\hline
\end{tabular}

certain extent to save a considerable amount of time and cost. For identification, diagnostics and genotyping methods using PCR will find the major applications of the present method. The purity of the template DNA prepared using rHTTP method suggests that it may not be suitable for restriction analyses or genome sequencings. The DNA templates prepared with rHTTP method has an excellent storability. At $-20^{\circ} \mathrm{C}$, templates can be stored for 1 month while at room temperature it could be stored for at least 3 days.

rHTTP method can be used for a variety of plant species belonging to Poaceae, Fabaceae, and Brassicaceae which encompass majority of the agriculturally important crops and most of the marker assisted breeding programs are targeted to these crops. Both random markers like RAPD and targeted amplification of Internal Transcribed Spacer (ITS) were obtained for all the plant species used. In order to further validate the applicability of the method, SSR markers were amplified in rice following the rHTTP method. This method can be very helpful in molecular breeding programs, plant genotyping where huge number of varieties or lines need to be screened using a large number of PCR based markers.

\section{Conclusions}

The rHTTP holds a number of advantages over most of the above mentioned protocols- (i) No requirement of ice, liquid nitrogen or lyophilization, (ii) No tissue grinding, (iii) No centrifugation, (iv) No harmful chemicals, (v) This is high throughput method. Unlike, other methods, average sample processing time goes down with increasing number of samples (vi) Equally efficient for fresh as well as old tissue, (vii) It can work for a wide range of plant species, (viii) Requires almost no technical expertise, (ix) A single prep can be used for more than 500 PCR reactions $(40 \mu \mathrm{l})$, (ix) The lysates have a month long shelf life when stored at $-20^{\circ} \mathrm{C}$, and $(\mathrm{x})$ Cost per preparation is very low as compared to any other direct PCR method or commercially available kit. Hence, the
rHTTP method described here is simpler, cheaper and more rapid as compared to other direct PCR systems reported till date and will be very useful in plant biotechnology projects having versatile PCR based applications.

\section{Methods \\ Plant samples}

A total of 21 different plant species belonging to 12 different families viz. Amaryllidaceae, Nyctaginaceae, Asteraceae, Apocynaceae, Solanaceae, Commelinaceae, Arecaceae, Fabaceae, Capparaceae, Verbenas, Poaceae, and Brassicaceae collected from different parts of India were used in the study (Refer Additional file 4: Table S1 for details of samples). All samples were collected in polypropylene bags and stored at $4{ }^{\circ} \mathrm{C}$ prior to use.

\section{Protocol development and optimization}

A linear gradient of 0.5 to $5 \%(\mathrm{w} / \mathrm{v}$ with an interval of 0.5\%) molecular biology grade Sodium Dodecyl Sulfate (HiMedia, India) prepared in MiliQ water was tested as lysis buffer. Final concentration of SDS was selected on the basis of DNA quantity and quality in the lysate prepared with two leaf discs. Initially, the lysis was done at $99{ }^{\circ} \mathrm{C}$ for $20 \mathrm{~min}$. Varying amount of tissue was used for optimizing the amount of start sample as it affects the quantity and quality of DNA template to be prepared. For this, variable number of leaf discs $(\sim 0.5 \mathrm{~cm}$, diameter) viz. one disc $(\sim 1.6 \mathrm{mg})$ and two discs $(\sim 3.2 \mathrm{mg})$ were used for lysis as mentioned above. After optimizing the concentration of SDS and amount of tissue to be lysed, the time for lysis was further optimized using two time periods for lysis viz. 10 and $20 \mathrm{~min}$ at $99^{\circ} \mathrm{C}$.

For protocol optimization, leaves of the rice variety HUR917 were used. For lysis, the leaf discs were placed in a $200 \mu \mathrm{l}$ PCR tubes (Tarsons, India) and $100 \mu \mathrm{l}$ of lysis buffer was added to it and heated in a thermal cycler at $99{ }^{\circ} \mathrm{C}$ (PeqStar, VWR International Ltd., UK). All lysis and spectrophotometric observations were carried out in five replicates. 
Initial assessment of DNA template quality and quantity DNA concentration and purity $\left(\mathrm{A}_{260} / \mathrm{A}_{280}\right)$ was determined using ScanDrop spectrophotopmeter (Analytik Jena AG, Germany).

\section{PCR assay}

For optimization of PCR amplification, crude lysate, 10X, and 20X dilutions of the lysates were used as template. Dilutions were prepared in MiliQ water. GoTaq ${ }^{\circ}$ Green Mastermix (Promega, USA) was used throughout the experiments. An aliquot of $2.5 \mu \mathrm{l}$ of the template was used in two reaction volumes viz. 20 and $40 \mu \mathrm{l}$. For $40 \mu \mathrm{l}$ reaction volume, $10 \mathrm{X}$ dilutions as well as $20 \mathrm{X}$ dilutions were used and for $20 \mu \mathrm{l}$ reaction volume, only crude extract was used. With an assumption that lysates will have a significant amount of PCR inhibitors, all PCR reactions were made in two sets, one with Bovine Serum Albumin (Promega, USA) as a PCR enhancer with a final concentration of $0.01 \mu \mathrm{g} / \mathrm{ml}$ and another without BSA. For comparison, bacterial genomic DNA suspended in 0.1\% SDS and TE buffer was also used for RAPD in a $20 \mu \mathrm{l}$ reaction volume.

\section{Primers and PCR conditions}

For optimization of initial PCR conditions, RAPD primers listed in Additional file 4: Table S2 were used. The following conditions were used-Initial denaturation: $94{ }^{\circ} \mathrm{C}$ for $45 \mathrm{~s}$, ten cycles of (denaturation: $94{ }^{\circ} \mathrm{C}$ for $45 \mathrm{~s}$, primer annealing: $45^{\circ} \mathrm{C}$ for $60 \mathrm{~s}$, primer extension: $72{ }^{\circ} \mathrm{C}$ for $2 \mathrm{~min}$ ), 30 cycles of (denaturation: $94{ }^{\circ} \mathrm{C}$ for $45 \mathrm{~s}$, primer annealing: $45^{\circ} \mathrm{C}$ for $45 \mathrm{~s}$, primer extension: $72^{\circ} \mathrm{C}$ for $2 \mathrm{~min}$ ), final primer extension: $72{ }^{\circ} \mathrm{C}$ for $10 \mathrm{~min}$. For comparison with other methods, both RAPD primers and universal plant internal transcribed spacer (ITS) specific primers were used (Additional file 4: Table S2) [22]. For amplification of plant specific ITS region, following PCR conditions were used- Initial denaturation: $94{ }^{\circ} \mathrm{C}$ for $4 \mathrm{~min}, 34 \mathrm{cycles}$ of (denaturation: $94^{\circ} \mathrm{C}$ for $30 \mathrm{~s}$, primer annealing: $58^{\circ} \mathrm{C}$ for $40 \mathrm{~s}$, primer extension: $72{ }^{\circ} \mathrm{C}$ for $60 \mathrm{~s}$ ), final primer extension: $72{ }^{\circ} \mathrm{C}$ for $10 \mathrm{~min}$.

\section{Effectiveness of the optimized method}

To check the effectiveness of the optimized method, it was tested on 11 different rice varieties, wheat, pigeonpea, mustard, soybean, pea, tomato, maize, march lilly, bougainvillea, Indian blanket flower, nerium, petunia, purple pirouette petunia, moses-in-the-cradle, golden cane palm, duranta, periwinkle, chrysanthemum, Dipterygium glaucum and Crotaleria burhia. SSR markers specific for rice viz. RM18398 and RM26108 (Additional file 4: Table S2) were used for amplification with rHTTP templates [23]. Further the effectiveness of the protocol was tested with the leaves of 2 months old leaf tissues of rice varieties PR108, PR111 and two other local varieties collected from Punjab, India.
The integrity of the template DNA prepared using optimized protocol during storage was studied by keeping the lysates at $-20^{\circ} \mathrm{C}$ or at room temperature. The lysates were stored at $-20^{\circ} \mathrm{C}$ for 30 days and PCR amplification was checked at an interval of 10 days. Likewise the lysates were kept at room temperature for a week and checked through PCR amplification at an interval of 3 days.

\section{Testing of the method using boiling water}

After optimization of all the parameters viz. SDS concentration, amount of tissue and time, the protocol was further tested for its execution using boiling water instead of thermal cycler so that it can be performed even outside the laboratory. For this, water was boiled on hot plate (Impact Icon Instruments Company, India) and temperature of the water was monitored with a digital thermometer (Frontier Multi- Thermometer, Model: ST9283, India). The PCR tubes containing leaf discs and lysis buffer were put into a beaker containing boiling water. Lysis was carried out for two time periods viz. Ten and $20 \mathrm{~min}$ as the surface temperature of the boiling water ranged from $\left(100-102{ }^{\circ} \mathrm{C}\right)$.

\section{Comparison with other similar methods}

Four quick plant DNA extraction protocols previously reported by- (i) Wang et al. (1993), (ii) Wang et al.(2016), (iii) Satya et al. (2013), and (iv) Steiner et al. (1995) were compared with the optimized protocol in terms of amplification profiles using RAPD and ITS specific primers. A comparison in terms of time, cost and instrumentation was also made with few popular commercial kits for plant DNA isolation.

\section{Supplementary information}

Supplementary information accompanies this paper at https://doi.org/10. 1186/s12896-019-0560-4.

Additional file 1: Figure S1. RAPD profile of 11 different varieties of rice using OPB06 primer. M: 100 bp marker (Promega); Lane 1: TKM 13; Lane 2: Rajendra Sweta; Lane 3: HUR 105; Lane 4: Improved Pusa Basmati 1; Lane 5: GM 96; Lane 6: GM 99; Lane 7: GM 137; Lane 8: GM 113; Lane 9: Pusa Basmati 1121; Lane 10: PR 115; Lane 11: PR111.

Additional file 2: Figure S2. RAPD profile (with OPB07) of four different rice using 2 months old leaf tissue. Lane 1: PR111; Lane 2: PR108; Lane 3: Local variety 1; Lane 4: Local variety 2.

Additional file 3: Figure S3. Gel photograph showing the results of ITS amplification using 3 days old template DNA of rice and wheat stored at room temperature. M: 100 bp marker (Promega); Lane 1: Wheat (var. HD2967); Lane 2: Rice (var. HUR917)

Additional file 4: Table S1. Details of plant samples used in the study. Table S2. Primers (RAPD, ITS, and SSR) used in the study. Table S3. Calculation of cost per preparation for rHTTP method.

\section{Abbreviations}

BSA: Bovine Serum Albumin; CRIJAF: Central Research Institute for Jute and Allied Fibers; DNA: Deoxyribonucleic acid; ICAR: Indian Council of Agricultural Research; IISS: Indian Institute of Seed Science; ITS: Internal Transcribed Spacer; LAMP: Loop Mediated Isothermal Amplification; NBAIM: National 
Bureau of Agriculturally Important Microorganisms; PCR: Polymerase Chain Reaction; RAPD: Random Amplified Polymorphic DNA; rHTTP: Rapid High Throughput Template Preparation; ROSE: Rapid One-step Extraction; SDS: Sodium Dodecyl Sulphate; SE: Standard Error; TE: Tris EDTA

\section{Acknowledgements}

Authors gratefully acknowledge the financial assistance received under the project entitled "Development of gene-chip for detection of major fungal plant pathogens" from ICAR Network Project on Application of Microorganisms in Agriculture and Allied Sector (AMAAS). Authors are thankful to Dr. Soham Ray, Scientist, ICAR-CRIJAF, Barrackpore, India for his inputs during the experiments using SSR markers.

\section{Authors' contributions}

$\mathrm{HC}$ conceptualized and designed the experiments. PC and SD executed the experiments. PC conducted additional experiments during the revision of the manuscript. PC with the help of SKS compiled the results and prepared the first draft of the manuscript. $\mathrm{HC}$ and $\mathrm{AS}$ revised the first draft of the manuscript. AKS edited and finalized the manuscript. All the authors have read and approved the manuscript in its current form.

\section{Funding}

This study was supported by financial assistance received from ICAR funded Network Project on Application of Microorganisms in Agriculture and Allied Sector (AMAAS). The funding agency did not play any role in the design or execution of the study including collection, analysis, and interpretation of data or in writing the manuscript.

\section{Availability of data and materials}

All data generated or analysed during this study are included in this published article.

\section{Ethics approval and consent to participate}

Not applicable.

\section{Consent for publication}

Not applicable.

\section{Competing interests}

The authors declare that they have no competing interests.

Received: 6 September 2018 Accepted: 10 September 2019

Published online: 26 October 2019

\section{References}

1. Langridge $U$, Schwall M, Langridge P. Squashes of plant tissue as substrate for PCR. Nucleic Acids Res. 1991;19:6954.

2. Edwards K, Johnstone C, Thompson C. A simple and rapid method for the preparation of plant genomic DNA for PCR analysis. Nucleic Acids Res. 1991; 19:1349 http://www.ncbi.n/m.nih.gov/pmc/articles/PMC333874/.

3. Doyle JJ, Doyle JL. A rapid DNA isolation procedure for small quantities of fresh leaf tissue. Phytochem Bull. 1987;19:11-5. https://doi.org/10.2307/ 4119796.

4. Williams JGK, Kubelik AR, Livak KJ, Rafalski JA, Tingey SV. DNA polymorphisms amplified by arbitrary primers are useful as genetic markers. Nucleic Acids Res. 1990;18:6531-5.

5. Aljanabi SM, Martinez I. Universal and rapid salt-extraction of high quality genomic DNA for PCR-based techniques. Nucleic Acids Res. 1997;25:4692-3.

6. Stewart CN. Rapid DNA Extraction from Plants. In: Micheli M.R., Bova R. (eds) Fingerprinting Methods Based on Arbitrarily Primed PCR. Springer Lab Manuals. Berlin, Heidelberg: Springer; 1997. p. 25-8.

7. Sharma R, Mahla HR, Mohapatra T, Bhargava SC, Sharma MM. Isolating plant genomic DNA without liquid nitrogen. Plant Mol Biol Report. 2003;21:43-50.

8. Ahmad SM, Ganaie MM, Qazi PH, Verma V, Basir SF, Qazi GN. Rapid DNA isolation protocol for angiospermic plants. Bulg J Plant physiol. 2004;30:25-33.

9. Manen J-F, Sinitsyna O, Aeschbach L, Markov AV, Sinitsyn A. A fully automatable enzymatic method for DNA extraction from plant tissues. BMC Plant Biol. 2005:5:23.

10. Varma A, Padh H, Shrivastava N. Plant genomic DNA isolation: an art or a science. Biotechnol J. 2007;2:386-92.
11. Allen GC, Flores-Vergara MA, Krasynanski S, Kumar S, Thompson WF. A modified protocol for rapid DNA isolation from plant tissues using cetyltrimethylammonium bromide. Nat Protoc. 2006;1:2320-5. https://doi. org/10.1038/nprot.2006.384.

12. Wang H, Qi M, Cutler AJ. A simple method of preparing plant samples for PCR. Nucleic Acids Res. 1993;21:4153-4.

13. Steiner JJ, Polemba CJ, Fjellstrom RG, Elliott LF. A rapid one-tube genomic DNA extraction process for PCR and RAPD analyses. Nucleic Acids Res. 1995; 23:2569-70.

14. Wang L, Wang R, Yu Y, Zhang F, Wang $X$, Ying $Y$, et al. A powerless on-thespot detection protocol for transgenic crops within 30 min, from leaf sampling up to results. Anal Bioanal Chem. 2016;408:657-62.

15. Satya P, Mitra S, Ray DP, Mahapatra BS, Karan M, Jana S, et al. Rapid and inexpensive $\mathrm{NaOH}$ based direct PCR for amplification of nuclear and organelle DNA from ramie (Boehmeria nivea), a bast fibre crop containing complex polysaccharides. Ind Crop Prod. 2013;50:532-6.

16. Zhang $L$, Wang $B$, Pan $L$, Peng J. Recycling isolation of plant DNA, a novel method. J Genet Genomics. 2013;40(1):45-54.

17. Zhang L, Dai $L$, Gou J, Peng J. An effective protocol to solve the problem in genomic DNA isolation of tung tree. J Plant Biochem Biotechnol. 2013;22(4): 492-97.

18. Berendzen K, Searle I, Ravenscroft D, Koncz C, Batschauer A, Coupland G, et al. A rapid and versatile combined DNA/RNA extraction protocol and its application to the analysis of a novel DNA marker set polymorphic between Arabidopsis thaliana ecotypes Col-0 and Landsberg erecta. Plant Methods. 2005;1:4.

19. Li Y, Zhao H, Yan X, Li M, Chen P, Zhang S. A universal method for direct PCR amplification of plant tissues. Anal Methods. 2017:9:1800-5.

20. Schrader C, Schielke A, Ellerbroek L, Johne R. PCR inhibitors - occurrence, properties and removal. J Appl Microbiol. 2012;113:1014-26.

21. Bondi CAM, Marks JL, Wroblewski LB, Raatikainen HS, Lenox SR, Gebhardt KE. Human and environmental toxicity of sodium lauryl sulfate (SLS): evidence for safe use in household cleaning products. Environ Health Insights. 2015;9:EHI-S31765.

22. Cheng T, Xu C, Lei L, Li C, Zhang Y, Zhou S. Barcoding the kingdom Plantae: new PCR primers for ITS regions of plants with improved universality and specificity. Mol Ecol Resour. 2016:16:138-49.

23. Ray S, Bose L K, Ray J, Ngangkham U, Katara JL, Samantaray S, et al. Development and validation of cross-transferable and polymorphic DNA markers for detecting alien genome introgression in Oryza sativa from Oryza brachyantha. Mol Genet Genomics. 2016;291(4):1783-94.

\section{Publisher's Note}

Springer Nature remains neutral with regard to jurisdictional claims in published maps and institutional affiliations.

Ready to submit your research? Choose BMC and benefit from:

- fast, convenient online submission

- thorough peer review by experienced researchers in your field

- rapid publication on acceptance

- support for research data, including large and complex data types

- gold Open Access which fosters wider collaboration and increased citations

- maximum visibility for your research: over $100 \mathrm{M}$ website views per year

At $\mathrm{BMC}$, research is always in progress.

Learn more biomedcentral.com/submissions 